\title{
EVOLUTION AND CONTROVERSIES REGARDING THE STANDARDIZATION, VALUATION AND AMORTIZATION OF THE GOODWILL
}

\author{
Ph.D. Student Popescu Aurora, Academy of Economic Studies, Bucharest \\ aurora.popescu@yahoo.com
}

\begin{abstract}
Summary: Goodwill is an intangible asset item and includes: valuable business contacts, geographical location, market outlets, reputation of business or product and other intangible assets which evaluation is extremely difficult. The amortization of the goodwill depends on the way of approach of the balance sheet. A legal approach, which emphasizes the principles of prudence and of the independence of every financial year, will tend to apply the amortization. On the other side, an accounting approach, which takes into account especially the going concern principle, will tend to replace the amortization with the effects of a impairment test on the goodwill( reversible lostindicated a provision).The International Accounting Standard IFRS 3 Business Combination considers the goodwill as the unidentified sum paid by a purchaser with the occasion of a business combination and presents the regulations of the booking the goodwill in the consolidated accounts.
\end{abstract}

Purchased goodwill is the surplus over the fair value of the net assets of the company which someone is prepared to pay for the business. There are different methods of valuation the goodwill. A current mistake is the focus on the momentarily static value of the assets of a company and on the history of the purchasing costs of its elements and not on the activities of the business that generate cash flow. Only after making this distinction one can determine the true and fair value of a business.

Relevant in this regard may be the value of the investments in intangible assets as information network, advertising, promotion, software and a favorable commercial location. These assets are not in general directly evaluated. However there are methods of evaluation as Discounted Cash Flow Method (DCF) which calculate this value through the generated profit. One of the main objectives in the present purchasing of companies is the acquisition of some of their intangible assets which do not appear in their balance sheet as brand name, quality of the research staff, the distribution network, the philosophy of the management, the audience of the company between its clients.

For investors very significant are the investments in intangible assets that can be taken over together with the fixed assets because these intangible assets have the power to increase the future activity of the purchased company and to generate profit.

According to Lassegue (1998) the goodwill consists in intangible elements, inclusive the right to the agreement, namely the amount paid ore owed the previous owner for the transfer to the buyer of the rights resulted both from the agreements and from the legislation concerning the commercial property, intangible elements which are not subject to an evaluation and are not separately registered in the balance sheet but which determine an increase of the future activities of the company.

1. Accounting and fiscal approach

In the Romanian general accounting plan the goodwill is booked in the count 207. It is calculated only after the purchasing of a company, as a difference between the purchasing cost and the value of the assets of the company which appear in the corresponding accounts. So the goodwill is a residual value.

From an accounting and fiscal point of view we mention the following particularities: 
- the goodwill is not subject to amortization in general; but if it is noticed an irreversible devaluation, it is amortized (it is deducted from its initial value);

- the expenses for the making up of the goodwill are not fiscal deductible.

2. Legal approach

The purchasing of companies and of businesses has raised many juridical problems concerning the transfer of the goodwill from seller to buyer. This transfer is difficult tu be stipulated in the purchasing contract because some elements of the goodwill remain bound to the business (location, reputation, products, competition, employees ) and other elements remain to the seller consisting in his personal qualities (management, relation with the clients and with the authority etc).

In general the seller commits through contract to not develop the same business in that region and to not attract his previous clients and employees. However nobody can stop those to follow their employer in other region or business.

3. Audit approach

The auditors are physical or juridical persons authorized to evaluate a company or a business when is needed. The approach of the auditors is the most synthetic and pragmatic one producing a new concept: market value added (MVA). MVA is the difference between the market value of a company and the cumulated value of the shareholders' investments and the reinvested profit. Through this concept the company is looked as a system in which liquidities are invested to generate future superior revenues.

According to the principle of prudence the goodwill is not to be booked in the ledgers if it was not purchase separately but was only created and developed during the normal activities of the company.

The value of the goodwill is superior to the value of its separated elements. Moreover some of these elements exist only connected to the whole activity of the company.

Sometimes the good will is taken as this added value and is named overvalue or purchasing margin.

\section{Controversies and evolution in the standards of goodwill amortization}

Can the goodwill be amortized or it has to be depreciated with a test?

The $4^{\text {th }}$ Directive and some national standards (the French and the Romanian one for example) encourage a rapid amortization (5 years at the most). It is difficult to establish the depreciation because the goodwill has to be taken into account as a whole and the elements which compose it are very different. Some of them has an objective value established by the market. Others have a juridical validity limited in time. Others suffer a moral wear and tear or lose their value through unpredictable ways.

These particularities lead to different conceptions regarding the goodwill.

The American Accounting Standard resorted to an amortization on a period of 40 years, while many countries that applied IAS 22 (abrogated in present) practiced an amortization on a period of 20 years. It is known that according to IAS 22 the good will had to be amortized systematically, during its service life. That service life could not be longer than 20 years from the date when it was initially recognized. So the companies enjoyed of flexibility regarding the period of time chosen for the amortization of their goodwill.

So, the companies with a good financial result were inclined to adopt short period of amortization in order to get rid as soon as possible of a future source of expenses. On the contrary the companies with bad financial results chose a longer period of amortization.

The American experts came to the conclusion that the optimal solution would be a depreciation test to determine the impairment. 
FAS 141"Business Combination" and FAS 142 "Goodwill and other intangible assets" adopted by FASB on 29June 2001 change the method of amortization of the goodwill with an annual test of impairment for the value.

In the present goodwill is treated according to IFRS 3Business Combination and represents the unidentifiable part of the amount paid by the buyer with the occasion of an acquisition of a company.

According to IFRS 3 all the business combination will be booked using the purchasing method and the goodwill purchased will be valuated, after the initial recognition, at the purchasing cost level minus the cumulated lost of value. In conclusion, the goodwill will not be amortized, but it will be checked annually or any sign of impairment of its value.

\section{The bookkeeping of the goodwill}

The goodwill will be booked according to the provisions mentioned in paragraph 5.22 a,b,c Section 1, Volume 1 Accounting Regulations harmonized with the $4^{\text {th }}$ Directive of CEE and with the International Accounting Standards. The goodwill will be recorded in books with the help of the account 207 Goodwill.

The goodwill is the difference between the purchasing cost and the fair value at the time of transaction of the net assets of the acquisitioned company.

The goodwill will be booked in the consolidated balance sheet at the amount equal with

- the difference between the purchasing cost and fair value of the net assets and the total amount of the surplus will be booked as an asset, although some of its components are not assets as such.

So, the goodwill which is measured as a residual sum comprises elements which could be in the following way:

a) some of them constitutes the core goodwill, namely intangible assets purchased which cannot be identified as other intangible assets than goodwill, for example human capital;

b) other elements are part of the goodwill because of the method of calculation, for example: over evaluated purchase cost or assets and liabilities which were not be booked at their true value in the consolidated balance sheet (assets and liabilities related to the deferred taxes or liabilities related to the employees), while the purchased cost reflects the true and fair value of the respective assets and liabilities.

IASB pointed out that all the elements of goodwill to be booked as assets, because the core part of the goodwill, which constitutes the main part, inclines to be more an asset than expense. procedure:

In the case of successive acquisitions of securities it will be used the following booking

a) it will be identified and valuated the purchased assets and liabilities and will be calculated the goodwill for every separate transaction;

b) then it will be reevaluated the share of the titles previous owned on the basis of the fair value at the most recent transaction having the counterpart in capital.

The increase of the reputation of a company admitted for transactions on the Stock Exchange can be quantified and its value will be booked in the account 207"Goodwill", increasing the asset value of the company.

\section{Goodwill and accounts consolidation}

The goodwill as an intangible asset is analyzed within the wider context of the accounts consolidation issue.

According to IFRS3 any operation which consists in combination of entities or activities in a unique entity that issue the financial statements is considered an operation of business combination.

As an example, the following transactions represent business combination: assumption of liabilities, purchasing of a share of the net assets of a company which represent one or many 
activities, without the purchasing of securities ; rare cases of mergers of equal companies ; transactions in which the purchasing date do not correspond with the transfer of the financial interests; agreements regarding different elements which form together an activity in the sense of IFRS3, for example, agreements of outsourcing (selling of machines, transfer of staff and of ongoing contracts) (PriceWaterhouseCoopers, 2006)

A number of regulations regarding the goodwill in the situation of account consolidation were elaborated:

- when the business is acquisitioned at a less value than its fair price, the difference is booked as a negative goodwill. It will be considered as an income and will be taken over in the profit and loss account as follows:

a) when the unfavorable results forecasted at the time of the acquisition take place or

b) when there is an income corresponding to the negative goodwill

- when a company is taken over by acquisition, its identified assets and liabilities will be included in the consolidated balance sheet at their fair value at the moment of acquisition;

- the share of the mother company and its subsidiaries in the capital of the purchased company will be compared with the acquisition cost ;

- the cost of acquisition means the cash amount or cash equivalent amount or the value of securities at the moment of transaction paid by purchaser to control the net assets of the company , as well as all the other expenses directly determined by the process of acquisition;

- by 'the fair value of net assets' of the acquisitioned company is understood its net assets at the moment of acquisition, the identified assets minus the identified liabilities;

- when the acquisition cost of the company surpasses its fair value, the difference will be considered as goodwill, otherwise it will result a negative goodwill. The goodwill will be amortized and the negative goodwill will be taken over in the profit and loss account.

- the consolidation of the accounts is realized through the compensation of the acquisition cost of the securities owned by purchaser with the corresponding part of these securities in the net assets of the consolidated company;

- when the securities are purchased consecutively, in order to be established the value of the goodwill it will be considered the acquisition date of the stock that ensure the control or a significant influence over the company. The ulterior acquisition of securities will generate, as a rule, new goodwill;

- when the group subscribe to an increase of capital at an already consolidated company, the goodwill will be calculated in function with the variation of the share that the group owned in the capital of the respective company, after the increase in capital;

- when a company is already globally integrated and the purchased company increase its control through new acquisitions of securities which generate a negative goodwill, after it will be taken over in the loss of the consolidated company, the residual amount will be compensated by an eventually goodwill resulted from the previous consolidation through global integration. As a result, in the balance sheet will appear only the balance of this operation.

- the cumulated value of the goodwill resulted from an acquisition transacted in the current or in a previous financial year will be adjusted with any identifiable goodwill of the subsidiaries sold before the date of the balance sheet;

- when the mother company owns equities or a subsidiary owns equities of the mother company, in the process of account consolidation the respective equities will be considered own equities, according to the provisions of the $1^{\text {st }}$ Volume of the Accounting Regulations harmonized with the $4^{\text {th }}$ Directive of the European Economic Community and the International Accounting Standards.

- when the acquisition has a significant effect on the consolidated accounts, the following information will be supplied: the book value and the fair value at the moment of acquisition for 
every category of assets and liabilities, the value of the goodwill or the negative goodwill, as well as an explanation of every significant adjustment performed;

- the going out of the consolidation area of a company as an effect of a giving up to securities will be performed at the moment of transaction or at the beginning of the financial year in he course of which the transaction took place.;

- the corresponding value of the sold titles, representing the share of its own equity, will be diminished or increased with the (negative) goodwill not amortized at the time;

- the balance between the amount received as a result of the sale of the subsidiary and the value of its net assets at the moment of transaction will be booked in the profit and loss account as profit or loss;

- when the income or the expenses of the sold company are significant compared to the consolidated result, they will be included in the booked consolidated result until the date of transaction;

- in case of deconsolidation of a company followed by a lose of the control or of a significant influence, without a transfer of the share stock, for example following some severe and lasting restrictions, the titles will be rebooked in the balance sheet for the share they represent on the date of deconsolidation, from the equity of the deconsolidated company, increased with the residual goodwill;

- the share of a company in another associated company, as well as the loss or the profit resulted from the participation (inclusive the eventually goodwill treated according to paragraph 5.22 a), b), c), Section 1, Chapter 1, Volume 1 of the Harmonized Accounting Regulations $-4^{\text {th }}$ Directive of EEC and with the IAS) will be reflected by the method of equalization.

The concept of combination in a unique entity which issues the financial statements refers to the consolidation through global integration within the same consolidated accounts.

The accounting of the company combination, according to IFRS 3 , will be performed through the method of acquisition and will be used the fair value.

All the combinations of companies will be booked according to the method of acquisition (rare exceptions are: combination of companies or activities under a conjunctive control; company combination that lead to shared association; company combination that imply more mutual entities and company combination with a unique contract without a financial participation).

The transfer of assets, in particular through partially contribution of assets or merging, when the transferred assets do not constitute an activity in conformity to IFRS 3 , it is booked through the allocation of the acquisition cost of these group of activities and assets to the transferred identified assets and liabilities, considered at their fair value at the moment of acquisition and without the booking of a goodwill.

\section{Conclusions}

The problematic of goodwill gave rise to disputes, most of them related to its identifying and amortization.

There are also arguments that deal with the technical aspects of the problem. We consider that the abandoning of the systematic amortization of the goodwill represents a progress, because so it is avoided the taking into account of a subjective period of use. Raffournier (2005) asserts that the performing of the annual test of impairment in conformity to IAS can be more difficult then the determination of the period of use. Some companies could use the goodwill as an instrument to adjust its financial result, diminishing the value of the assets arbitrarily. In this sense a systematic amortization would be applied indifferent of the financial results of the purchaser.

The convergent process between the international legislation and the American one enjoyed a strong support from the part of the European Commission. According to the president of the IASB, Sir David Tweedie, and the Commission of American Exchange Security on a medium term the following elements are in view: a technical support to facilitate the use of the concept of true and 
fair value; the obligation to book, report and issue a comprehensive income statement; an adhesion to the American model of a report on segments. A detailed application on short term of the concept of true and fair value is less probable. The president of the international organism has supplied to the Committee of Accounting Regulations (part of the organism that work for the adoption of the IFRS standards at the European level) details referred to the subjects for a process of convergence.

In this sense there are in view projects as: company combination (development and revision of the standard IFRS 3); the distinction liabilities/ equities; financial instruments; the process of identifying; information regarding the performance; income accountancy; the measurement of a fair value.

The path to an international and European accounting system of the Romanian companies pass trough the assimilation of the convergence process that is taking place between the two accounting referential organisms.

The companies quoted on the financial market, the insurance companies and other companies will have to impleme nt from the next year this international system. Such a mission is at the same time the result of the dealing of the Romanian companies in a global economic context.

\section{Bibliography}

1. Feleaga L, Feleaga N (2005), Financial Accounting: an European and international approach, $2^{\text {nd }}$ vol, Infomega Publishing House, Bucuresti

2. Feleaga N, Malciu L (2004), The challenge of the international accounting between the $2^{\text {nd }}$ and the $3^{\text {rd }}$ millennium. Evaluation models and intangible investments. Economic publishing house, Bucuresti

3. Lassegue $\mathrm{P}(1998)$. Accountancy. Lexicon. $4^{\text {th }}$ edition, Dalloz publishing house, Paris

4. Raffournier B.(2005). International accounting regulations, $2^{\text {nd }}$ edition, Economic publishing house, Paris

5. Feleaga N, Feleaga L . Disputes regarding the valuation, amortization and booking of the goodwill. The Academy of Economic Studies, Bucuresti.

internet resources:

www.iasb.org/

www.hmrc.gov.uk/manuals/

www.accaglobal.com/

www.iasplus.com/standard/ias 38.htm

www.capital.ro

www.biblioteca.ase.ro

www.economieteoreticasiaplicata.ro

www.resursejuridice.ro 